\title{
CBC e sociedades cirúrgicas
}

\section{$C B C$ and surgical socities}

ECBC-MG Alcino LÁzARO da Silva*

O que aprendi com os antepassados mais remotos; com Renato Pacheco Filho e vários presidentes e suas diretorias, o Colégio Brasileiro de Cirurgiões (CBC), desde 1929, prega o congregar, o formar e a defesa do Cirurgião.

A sua base inicial que sustenta os objetivos mais genéricos foi e é o Cirurgião Geral (CG).

Nesses oitenta anos de atividades ininterruptas, aqui e ali, expandindo-se do Rio de Janeiro para todo o Brasil, e numa extensão à América Latina, mudaram os tempos, os conceitos e os interesses de mercado além da constante busca de melhor qualidade.

O CG ficou no comum, no prevalente e na vanguarda do atendimento, muitas vezes, com adjetivos diferentes, v.g., do Trauma, Laparoscópico, Geriátrico, Oncológico, Ambulatorial e em Urgência.

O mercado e o desenvolvimento tecnológico criaram um corpo clínico gigantesco em exigências propedêuticas e terapêuticas e o caminho foi o aparecimento e o crescimento das especialidades, todas filhas íntimas da geral.

Para não omitir alguma, deixo de citá-las, mesmo porque não há importância no argumento que se está querendo desenvolver. Não há necessidade de citá-las porque há um denominador comum que é a origem de todas na Cirurgia Geral.

Com o nascer, o seu desenvolvimento e o seu crescimento, cada especialidade se viu presa à necessidade de soltar-se da casa materna e alçar voo. Neste, mostrar tudo de bom e útil que possui em favor da qualidade e dos recursos que a tecnologia nos vem impondo.

O CBC, então, de repente, viu-se restrito ao CG porque cada profissional pertencente à tecnologia se juntou a novos pares e não mais passou a conviver no CBC, de uma forma administrativa, política e até econômica.

Os nossos administradores, surpreendidos com os seus brotos, criando novas árvores, acordaram que era preciso conveniar-se.

Quero crer que nova era instalou-se no CBC criando convênios com algumas sociedades, que possuem o gen do CG e não necessitam mais da sua administração.

Os convênios entre sociedades são saudáveis porque reatam vínculos avoengos sem qualquer um dos conveniados se descaracterizar ou se despersonalizar. Cada um crescendo, não afetou o CBC que continua a ser a sociedade máter e agasalhadora.
Quando, no entanto, se revê os nomes das filhas que se foram encontra-se na listagem a auto-afirmação de cada uma e a convivência entre elas e a base inicial, que é o CBC.

Satisfação bilateral certamente, mas na releitura dessa lista não se encontra um nome importante para a Academia e para a atividade, a que pretendo me referir, ou seja, a Cirurgia Experimental.

Há um lugar reservado para ela, quase que a propósito, no setor do CBC que se denomina "Fórum de Pesquisa".

Por quê a Cirurgia Experimental e o Fórum de Pesquisa podem se unir, num convênio em que encontrarão eco para um grupo de cirurgiões? Porque ele abrirá as portas para um tipo de Cirurgião que denominamos Cirurgião Acadêmico em cujo seio se agasalha ou se aninha um profissional que não cabe em nenhuma das outras especialidades. É o cirurgião que milita na Academia, pesquisa, educa e ensina sem se preocupar em desdobrar-se em atividades clínicas paralelas para a sua sobrevivência.

A Sociedade Brasileira para o Desenvolvimento da Pesquisa em Cirurgia, Sobradpec, foi criada, por sonhadores, para atender ou aglutinar esse tipo de profissional tão útil à universidade, cobrindo um claro que reclama o seu lugar e espera, um dia, o reconhecimento do seu trabalho, no caráter administrativo, filosófico, cultural e até econômico.

Como o Congresso de Cirurgia Experimental vai se realizar nas dependências do $C B C$, e com a sua ajuda, surgirá uma oportunidade feliz para estabelecer-se um Convênio no qual se entregaria à Sobradpec a orientação do Fórum de Pesquisa do CBC que vem se repetindo com sucesso há alguns anos.

Quais as vantagens dessa união em que ambos se mantêm personalizados?

Para a Sobradpec a oportunidade de enriquecer o fórum pois ele cuidaria do que ela pretende, no íntimo, que é a pesquisa em nível experimental.

Para o CBC, a ajuda de uma Sociedade, bem constituída, que de um lado dá a mão a outra em nível clínico e recebe de volta a mão que integra o cirurgião geral e o pesquisador que aspira espaço para progredir sem competir em reserva de mercado.

Qual o dividendo maior? É mostrar às outras sociedades que é possível uma convivência intelectual sem despersonalizar-se. 
O CBC oferece a tradição, a experiência e sua organização, mantendo-se o filho primeiro e o norte de todas as conveniadas ao gerar novos valores e novas sociedades exigidas pelas tecnologias de avanço.

As conveniadas trarão o que há de mais recente no arsenal propedêutico e terapêutico, revitalizando a sua origem e dando ao Cirurgião Geral a grandeza que ele merece e aspira, para sempre reproduzir-se em profissionais bem formados.

* Professor de Cirurgia e Emérito da UFMG. 